\title{
POLISH LABOUR LAW 10 YEARS AFTER THE ACCESSION TO THE EUROPEAN UNION (CERTAIN ISSUES LINKED TO THE DETERMINATION OF THE DIRECTION OF CHANGE)
}

1. The key events which in the recent decades have had an impact on the development of Polish labour law certainly include the break-up with the communist past and the ensuing political and economic system transformation, and integration with the European structures, in particular Poland's accession to the European Union. Particularly significant at the time was the choice of the axiological foundations of this branch of law. It went without saying that it was requisite to discard the underlying values of socialist labour law informed by purely ideological criteria. Primarily, this applied to the egalitarian formula of equality coupled with the precedence of collective interest (to a large extent defined by the ruling party and respecting the system of state ownership) over individual interest. In this situation, the change of the vector to individual freedom could not have raised more serious doubts. This was reflected both in the Constitution adopted in 1997 and, to a certain extent, in the fundamental amendment to the Labour Code a year before. One proof of that axiological revaluation, in the first place, were the regulations, where the right to work, previously prominent and of socialist provenance, was replaced with freedom to work. This, however, did not mean that freedom became the sole value that informed the nature of the institution of labour

* Professor, University of Lodz, Faculty of Law and Administration, Labour Law Chair, 90-232 Lodz, Kopcińskiego 8/12, Poland.

** Ph.D., University of Lodz, Faculty of Law and Administration, Labour Law Chair, 90-232 Lodz, Kopcińskiego 8/12, Poland. 
law. A return to the completely unrestrained freedom of contract, characteristic of the early capitalist era, would have consequently shattered the raison d'être of this branch of law, i.e. its protective function based on the stipulation - in traditional approach - that the interests of the weaker party to the employment contract need to be protected. Labour law, therefore, cannot unreservedly respect the legal maxim "volenti non fit iniuria". While granting individuals the freedom to decide of their professional careers, it should concurrently guarantee their freedom from the threats to other values, such as fair social security, safety and health, dignity at work, privacy, and family development. Hence, the axiological determinant of the directions of labour law development should be the universal human rights that today represent an unquestioned standard of international law and the laws and regulations of the European Union. It is worth underscoring that another standard of the kind is equality, understood - to put it simply - as the freedom from discrimination. For it is doubtless that from the point of view of justice it is improper to consider equality of treatment as an intrinsic value, in as much as it is inappropriate to use unreasonable discrimination which stands in complete opposition to equality. At this point it would be possible to provide numerous examples confirming that in the recent years these values have been top priority for Polish legislature. This can be seen in the regulations concerning the principles of labour law, e.g. the principle of protection of dignity and other personal interests of employees, and the principle of non-discrimination, in the regulation on mobbing, or in the highly elaborate occupational safety and health regulations. Their current shape is certainly and to a large extent the result of implementation of the legal acts adopted by the European Union, which obviously does not settle that the legislation adopted in this respect is fully correct.

Having identified the foregoing axiological foundations of Polish labour law, it also takes to consider whether it should be exclusively oriented around the values associated with just one party to the employment contract, i.e. the employee. It would be wrong if regulations in this branch of law ignored the values attributed to the other party, the employer. This cannot be justified by the usually stronger position of the employer, both in the phase preceding the employment contract and in the phase of its performance. Protection of the interests of employees does have its limits, and going beyond these borderlines might also harm those who are meant to be protected. Labour law, therefore, should not stand in opposition to ownership rights and economic freedom. Any and all protective norms are meaningful in as much as employers pursuing their business objectives are willing to employ staff. It is difficult to assume that this willingness is informed by a moral imperative, rather than by economic conditions. One should not miss in the field of attention the patent conclusion that employment contracts have an instrumental dimension, for they serve entities other than employees to achieve certain goals. Excessive employment costs, too big hindrances to the management of human 
resources policies, and insufficient flexibility of the legal solutions concerning employment contracts may lead to such consequences which, from the perspective of labour law, are adverse, e.g. escaping employment contracts and replacing them with other legal or even illegal substitutes, or employment downsizing. The symptoms of this phenomenon are visible in Poland. High employment costs (especially insurance and parainsurance contributions), high social risk carried by employers, excessive job stability, and a plethora of prohibitions from terminating employment contracts are the reasons why the practice of entering into civil law contracts instead of employment contracts is becoming commonplace, and employment in the so-called grey zone is growing. This said, it appears that Polish labour law, while it has never ceased to protect employees, must increasingly promote employment, and this requires a greater focus on the values of importance to employers ${ }^{1}$.

2. In the ongoing debate in Poland on the future of labour law of late more and more attention has been paid to its scope of application. Above all. Increasingly popular is the view that regulations in this branch of law need to go beyond the conventional perception of employment contracts which assume subordination of the employee to the employer, hence it is claimed that labour law, whose significant part is social law, as it is linked to satisfying human needs through work, "is the law for working people, not the law for employees". Some authors suggest the need for change of its name from labour law to employment law ${ }^{3}$. This obviously refers to the afore-mentioned tendency to replace employment contracts with civil law contracts or self-employment, both considered to be less costly for employers and more convenient in terms of the opportunity to respond to the variable demand for labour in the market. In any discussion on this subject, the starting point must be that it takes to respect two principles: the principle of freedom of contract, as set forth in Art. $353^{1}$ Civil Code ("the contracting parties may arrange the legal relationship between them at their discretion") and the principle of economic freedom, the foundations of which are laid down in the Constitution of the Republic of Poland (Art. 20) and in the Economic Freedom Act of 2 July, 2004 (cf. Art. 6 in particular) 4 . Any restrictions on the options of choosing the legal basis of performing work, therefore, must be considered disallowable, unless the legal basis chosen is intended to conceal the actual nature of employment,

1 This subject is broadly discussed by M. Skąpski, Ochronna funkcja prawa pracy $w$ gospodarce rynkowej [Protective Function of Labour law in Market Economy], Kraków 2006, p. 139 and following.

2 A. Sobczyk, Prawo i człowiek pracujący - między ochrona godności a równości [Law and A Working Man - Between Protection of Dignity and Equality], [in:] M. Skąpski, K. Ślebzak (ed.), Aksjologiczne podstawy prawa pracy i ubezpieczeń spolecznych [Axiological Foundations of Labour Law and Social Insurance], Poznań 2014, p. 46.

3 In particular M. Gersdorf, Prawo zatrudnienia [Employment Law], Warszawa 2013.

4 OJ 2004, No. 173, item 1807, as amended. 
which most often boils down to simulating civil law contracts. Hence, if the dissimulated contract were an employment contract, in no way would it be possible to classify, in terms of a breach of the freedom of contract, a challenge to the validity of the contract disclosed by the parties thereto on the grounds that it bears the characteristics of ostensibility. This is acknowledged by the existing Art. 22 section $1^{1}$ and section $1^{2}$ of the Labour Code which provides that the disclosed contract must be compared with the definition of employment contract. It would be difficult to reconcile with this principle the thesis that the Labour Code establishes a presumption of conclusion of an employment contract, as is now and then claimed in the literature on the subject. In terms of the prospects of labour law's development much more important is the conclusion that civil law contracts and employment contracts in a significant proportion of cases may be lawful alternatives, therefore they may compete with one another. The attractiveness of civil law contracts certainly can be and is (as proven by the statistical data) a challenge to labour law. The upturn tendency to depart from employment contracts in favour of civil law contracts, motivated by economic factors, would run the risk of creating a situation in which labour law would regulate employment mainly in the non-economic sphere. This provokes the question what needs to be done so as to prevent this branch of law from shrinking. Different options are possible here. The first one is to identify the need for a specific expansion of labour law so that it covers the civil law bases of employment. This would entail a change to the nomenclature, as mentioned herein above. The legal regulation so expanded and reaching beyond employment contracts would be named "employment law". One part of it, though not its sole component, would be the right to employment contract ${ }^{5}$. Another consequence of this proposition, if accepted, might be - as is predicted - the enactment of the employment code $\mathrm{e}^{6}$. Characteristically, this concept preserves the structural severance of employee and non-employee work agreements and concurrently recognises certain common characteristics between them that justify their encapsulation within a single branch of law, i.e. employment law. Interesting as this concept is, it does have some material flaws. First of all, these include highly unclear relations with civil law. Hence, the doubt arises whether civil law contracts included within the scope of employment law cease to be an institution of civil law. Contracts of service, or more precisely contracts for provision of services, which are subject to the regulations applicable to contracts of service, contracts for service or other civil law agreements do not cease to be regulated by the Civil Code, no matter to what extent they determine the social status of the party working on those contracts, while they represent an alternative

5 This subject is more broadly discussed by M. Gersdorf, op. cit.

${ }^{6}$ M. Gersdorf, Kodeks zatrudnienia wyzwaniem przyszlości [Employment Code As A Future Challenge], [in:] M. Gersdorf, M. Raczkowski, R. Wyziński, Zatrudnieni i zatrudniajacy na aktualnym rynku pracy [Employees and Employers On the Current Labour Market], M. Gersdorf (ed.), Warszawa 2012. 
form of employment to employment contracts. A completely different issue is whether in respect of the persons working on such contracts, exactly for the reason of the role such contracts play, which is similar to that fulfilled by employment contracts, it would be reasonable to apply certain regulations applicable to employees. It appears that this is the right direction of change to the existing law. Such changes could prevent the escape from employment contracts while respecting the principle of freedom of contract. Importantly, such measures of the legislature are supported by the Constitution which in Art. 24 provides that work is under the protection of the Republic of Poland. It would be wrong to assume that this only applies to work done on the employment contract ${ }^{7}$. This provides the grounds for extending at least some of the labour law regulations so that they also cover non-employee work agreements. In certain cases this would even help Poland to meet its international obligations. The right to form trade unions granted to persons working on civil law contracts should be assessed exactly in these terms ${ }^{8}$. Also, it would be difficult to question the reasonability of extending to non-employees such legal regulations which, to date, have been primarily and exclusively addressed to employees and which typically have the social dimension (fair pay, safety and health protection, protection of family life, the right to rest and leisure) $)^{9}$. This must be concomitant with the extension of the subjective scope of the social security law so as to prevent diversification of the ensuing employment costs relative to the legal relationship based on which work is performed.

With this outlook it is unnecessary and unreasonable to create a new branch of law (employment law) or to designate a subjective scope of labour law other than the existing one. This law should continue to cover employment contracts and the ensuing legal relations. However, a far reaching revision is required with regard to the outlooks on the taxonomic characteristics of the employment contract, in particular the perception of the employee's subordination to the employer, which still is the fundamental criterion that delimits employment contracts and civil law contracts. The point of reference here cannot be the subordination paradigm characteristic of the employment relationships existing in the early formative period of labour law and consisting in subordination to the employer's directions in all aspects of the performance of the agreed work ${ }^{10}$. In this state

7 A. Sobczyk, Prawo pracy w świetle Konstytucji RP [Labour Law in the Light of the Constitution of the Republic of Poland], Vol. I: Teoria publicznego i prywatnego indywidualnego prawa pracy [Theory of Public and Private Individual Labour Law], Warszawa 2013, p. 68.

8 More broadly discussed by Z. Hajn, Prawo zrzeszania się w zwiazkach zawodowych - prawo pracowników czy prawo ludzi pracy [The Right to Form Trade Unions - the Right of Employees or Working People?], [in:] A. Wypych-Żywicka, M. Tomaszewska, J. Stelina (ed.), Zbiorowe prawo pracy $w$ XXI wieku [Collective Labour Law in the $21^{\text {st }}$ Century], Gdańsk 2010.

9 A. Sobczyk, Prawo i człowiek pracujacy... [Law and A Working Man...], p. 42-43.

${ }_{10}$ L. Mitrus, Podporzadkowanie pracownicze jako zmieniajaca się cecha stosunku pracy [Employee Subordination as a Variable Characteristic of Employment Contract], [in:] L. Florek, 
of affairs it would be difficult to justify the possibility of demonstrating, within the framework of employment contract, money-earning activities characterised by a certain degree of self-reliance. In no way can it be denied that this stereotype has been established by the change of the definition of employment contract enacted in effect of the Labour Code amendment in $2002^{11}$. In as much as prior to the said amendment, while defining the employment contract the legislature generally indicated the directorial position of the employer in the course of the given work being performed for him by an employee, in the version currently in place the legislature adds that the employer also designates the place and time of that work. This kind of clarification of the definition of employment contract may help delimit the employment contract and civil law contract, but it certainly does not help to extend the scope of application of the former one. The effect appears to be opposite. Today employees are expected to be more and more creative and self-reliant in the fulfilment of their tasks. Consequently, the existing subordination formula becomes highly anachronistic. Therefore, one needs to be very cautious when assessing the nature of the employment contract being concluded by referring to the criterion of subordination/self-reliance. This is already demonstrated in the judicature, in particular in the doctrine which allows for the existence in employment relations of the so-called autonomous subordination, although the ensuing risks are recognised, too ${ }^{12}$. Apparently, each and every job done for another entity under the circumstance of any dependence of that entity (including economic dependence) may be performed on employment contract, whatever the degree of self-reliance in the fulfilment of the employee's tasks (especially if other characteristics typical of employment contract applied). In such a case significance should be attached to the mutual consent between the parties which, when selecting the type of the work agreement, also determine whether the same will be subject to labour law or civil law. Obviously, exclusion of self-reliance in the performance of work thwarts the option of concluding a civil law contract and is indicative - if such a contract has been concluded - of the intent to conceal employee employment. The voiced concerns that making the choice of the basis of employment dependent on the freedom of the parties in a situation where no classical subordination applies may encourage employers to impose the content of employment contracts and the applicable legal regime (labour law - civil law), are to a large extent reasonable. Nevertheless, they would lose their sharpness in the event when some of the norms, to date exclusively addressed to employees, are extended to civil law forms of employment.

Ł. Pisarczyk (ed.), Współczesne problemy prawa pracy i ubezpieczeń społecznych [Contemporary Issues of Labour Law and Social Insurance], Warszawa 2011, p. 123 and following.

11 OJ, No. 135, item 1146.

12 Cf. M. Raczkowski, O podporzadkowaniu autonomicznym - krytycznie [On Autonomous Subordination - Critique], [in:] L. Florek. M. Pisarczyk (ed.), Wspótczesne problemy prawa pracy i ubezpieczeń społecznych, p. 131 and following. 
While preventing the escape from employment contracts to civil law contracts it is also worthwhile to consider the need to deepen the differentiation of the legal status of employees in relation to the degree of their self-reliance in the fulfilment of their tasks. In the case of executives managing businesses for and on behalf of employers it may be seriously doubtful whether employment contract is the basis of employment that is adequate to their position. Nevertheless, it cannot be disregarded that the legislature itself allows for the option of applying employment contract to them (e.g. in relation to directors of state enterprises this is the obligatory basis of employment). Opinions are divided, too, in the matter of applying employment contracts to members of management boards of limited companies ${ }^{13}$. Even if we agreed that top managers may work on employment contracts, it should be deemed right that applying to them all the protective labour law regulations would be unreasonable. Their negotiating power in confrontation with the employer and their financial standing suffice to guarantee effective protection of their interests without the need for support from labour law regulations. The foregoing conclusion may also be extended to other categories of managers ${ }^{14}$. For similar reasons it is also justified to extend their scope of participation in the risks carried in principle by the employer (especially the economic risks).

Another example of the necessity of differentiating the application of labour law regulations that could increase the attractiveness of employment contracts over civil law contracts is the issue of the legal position of employees relative to the criterion of employer size. Doubtlessly, a significant proportion of employers in Polish economy is represented by small and medium entrepreneurs. Simultaneously, they are the employers who most often choose the forms of employment that are alternative to employment contracts to avoid the difficulties linked to employment contracts. This is the sphere which confirms the thesis that the excessively protective function of labour law turns against the beneficiaries of this protection. It is difficult not to notice that the need for differentiation of the legal norms binding employers who employ small groups of employees is already reflected in Polish labour legislation. One example may be, e.g. the exclusion of the regulations on the so-called economic redundancies in relation to employers who employ fewer than twenty employees. Notwithstanding the objections raised by such differentiation in view of the principle of equal treatment, it nevertheless needs to be considered whether its scope should be extended, given the special nature of the relations between employees and employers at small companies, as

${ }_{13}$ More broadly discussed by T. Duraj, Podstawy zatrudnienia menedżerów najwyższego szczebla w przedsiębiorstwach [Bases of Top Managers' Employment by Enterprises], Warszawa 2006, p. 204 and following.

14 A. Sobczyk, Prawo i człowiek pracujacy... [Law and A Working Man...], p. 43. 
well as the economic potential of the employers. For instance, it is unreasonable to apply to them the regulations on reinstatement, or many other regulations reinforcing the protection of job stability ${ }^{15}$.

3. Like in many other countries, also in Poland the question about the future of labour law is strictly linked to the position of trade unions. It is difficult not to admit that to date the development of this branch of law has been largely affected by trade unions' reclamations. This was so because trade unions appeared to be a great and well-organised force that was able to oppose employers by making use of the legion, and well-established over many years, rights and authorities (to bargain and enter into collective agreements, and take industrial actions, in particular including strikes). The power of trade unions was facilitated by the organisation of labour which relied on large industrial plants with numerous payroll. Currently, we are witnessing the reverse trend. Trade unions are losing much of their original attraction for working people. This is so for a variety of reasons. The first one to be indicated is the development of the tertiary sector. Certainly, this is not a trade union-friendly environment, if only due to the number of employees hired by service companies and a certain atomisation of workers' groups employed by such companies. Secondly, the gradual but already evident growth of the wealth levels in Poland and ever-increasing middle class are not conducive to popularity of traditional trade unions' slogans primarily addressed to the people working for large industrial plants. Thirdly, trade unions' popularity is not served well by the bureaucratisation of their headquarters and alienation of the trade union apparatus, whose objectives are not always convergent with those of the working people. Fourthly, as was the case with other post-communist states, following the system transformation Poland, too, has seen a rapid development of the private sector which is prevailing at the moment. In this sector, trade unions' formation and activities come up against serious obstacles of various natures. And fifthly, it is not favourable to trade unions that momentum has been gained by non-standard employment agreements, whose one characteristic is that the employee-employer relationship is never permanent. The existing experience, however, teaches that trade unions most strongly rely on employees with stable position in the workplace. Consequently, on the part of employees we can observe a decreasing interest in their membership of trade unions. Trade union members represent but a fraction of all employees, and in a significant proportion employers maintain no trade union organisations at all. Trade unions are only still powerful in certain segments of the economy, especially where privatisation processes and economic rationality are finding it most difficult to pave the way. This surely gives rise to the question how reasonable it is, if at all, to keep up trade unions' monopoly

15 Cf. A. Sobczyk, Różnicowanie praw (ochrony) zatrudnionych-wybrane kryteria i ich ocena [Differentiation of the Rights (Protection) of the Employed], [in:] M. Bosak (ed.), Funkcja ochronna prawa pracy a wyzwania wspótczesności [Protective Function of Labour Law and the Contemporary Challenges], Warszawa 2014, p. 11-12. 
of representing the rights and interests of employees. It appears that in the future this monopoly is going to be increasingly broken. The symptoms are clear to see already. In a number of labour law regulations certain authorities are granted to employee representations other than trade unions and appointed in a manner approved by the given employer (this, however, usually takes place where no trade unions are present). For instance, employers can work closely with such representations in case of group lay-offs (the Act of 13 March, 2003 on special rules of terminating employment contracts for extraneous reasons ${ }^{16}$ ), or enter into agreements to suspend labour law regulations (Art. $9^{1}$ Labour Code). One institutional expression of this trend are employee councils stipulated in the Act of 7 April, 2006 on providing information to and consulting employees ${ }^{17}$. It also seems necessary to review the existing organisational model of trade unions, as set forth in Polish laws and regulations. In particular, it is extremely dubious that this model is based on the stipulation that trade unions' tasks to represent employees' interests and defend employee rights should be fulfilled by organisation structures operating on the level of the workplace. Alternative solutions, e.g. outsourcing such trade union tasks, would be conducive to strengthening not only trade union activists' independence from employers, but their effectiveness in providing employee protection, as well. Concentrating trade unions' authorities on the level of the workplace carries a number of inconveniences, a part of which is sure to ensue from the amalgamation of the function of a trade union activist with the status of an employee employed by an employer, whom the trade union has to confront from time to time in various employee matters. It goes without saying that this configuration is inherently conflicting. It implies the necessity to protect the permanent nature of trade union activists' employment contracts. The scope of this protection laid down by Polish legislation (ban on terminating the employment contract without consent of the workplace trade union organisation, regardless of the reasons for termination), however, goes beyond any reasonable limits, as it is conducive to trade union members abusing their protection rights. In this light it could be considered whether it would suffice to indicate trade union activism as the prohibited motivation for terminating an employment contract and couple such termination with a reasonably high indemnity that would be adjudicated in the event of an employer breaching this ban. Other doubts relate to the various facilitations, granted by Polish legislation to workplace trade union organisations, which cause financial burdens to employers ${ }^{18}$. These must be acknowledged to

16 OJ, No. 90, item 844, as amended.

17 OJ, No. 79, item 550, as amended.

18 More broadly discussed by Z. Góral, Utatwienia $w$ działalności zakładowej organizacji związowej - wybrane uwagi na tle przepisów ustawy o zwiąkach zawodowych [Facilitations for Workplace Trade Union Organisations - selected comments against the background of the Trade Unions Law], [in:] Z. Hajn (ed.), Związkowe przedstawicielstwo pracowników zakładu pracy [Trade Union Representation of Employees in the Workplace], Warszawa 2012, p. 459 and following. 
pose a particular danger to trade unions' independence. Finally, it feels right to conclude that a workplace trade union organisation structure is not a model that could be applied to exercise the freedom of association of persons working on civil law agreement. This is essential, as the requirement to respect the freedom of coalition of this category of employees, as mentioned herein above, results from the provisions of international and constitutional laws.

4. One of the issues most vividly discussed in the recent years and concerning Polish labour law is its recodification. This year is the $40^{\text {th }}$ anniversary of the Labour Code's enactment. This means that the Labour Code was enacted in entirely different political and economic conditions, when codification was perceived in definitely ideological terms, but was at the same time considered to bring the quality of law on a higher level. The enactment of the Labour Code was also viewed as an act which explicitly confirmed the severance, though not a complete splitup, of this branch of law from civil law. The later development of labour law, especially in the period of political and economic transformation - from the formal point of view - consisted in amending the Labour Code 1974 and adopting the acts concerning the matters not regulated by the Code, usually completely new and responding to the challenges of free market economy. A significant range of non-code regulations surely helped to reduce the meaningfulness of the code itself and rendered it difficult to convincingly claim that Polish labour law was fully codified. Which it had not been already at the time of the enactment of the Labour Code which was far away from meeting the requirement of completeness. The processes described above provide the basis for identifying two visions of Polish labour law's development. The first one is a specific kind of decodification, i.e. putting the emphasis on non-code norms included in other acts, but also (or especially, perhaps) in the acts negotiated by the public partners. The second proposition is to enact a new Labour Code, or in other words - recodify labour law in keeping with the requirements of free market economy and the standards applied within the European Union ${ }^{19}$. That the latter variant has been chosen may have been proved by the nomination of the Labour Law Reform Committee which prepared a draft new Labour Code. Committee members expressed their conviction that recodification was requisite in order to tidy up Polish labour law, and the obstructions in the way was not so much the subject matter itself, but rather the lack of political will ${ }^{20}$. Importantly, the draft Labour Code has not triggered any specific legislative work and this is unlikely to change any time soon.

19 Cf. M. Seweryński, Problemy rekodyfikacji prawa pracy [The Issues of Labour Law Recodification], [in:] M. Matey-Tyrowicz, L. Nawacki, B. Wagner (ed.), Prawo pracy a wyzwania XXI wieku. Ksiegga jubileuszowa Profesora Tadeusza Zielińskiego [Labour Law and the Challenges of the 21 $1^{\text {st }}$ Century. Jubilee Book of Professor Tadeusz Zieliński], Warszawa 2006, p. 319 and following.

20 W. Sanetra, Co dalej z kodyfikacja (rekodyfikacja) prawa pracy? [What About the Codification (Recodification) of Labour Law?], „Praca i Zabezpieczenie Społeczne” 2008 [“Labour and Social Security" 2008], No. 3, p. 8. 
It seems that the issue of recodifying Polish labour law is by far more complex and material counterarguments of various nature may be raised against this proposition. First of all it is not by accident that in the decisive majority of states with well-established free market economy labour law has not been codified, notwithstanding a number of attempts to do so. Primarily it is raised that the subject matter of this branch of law materially varies from the subject matter of civil law or criminal law which are characterised by relative stability and founded on concepts of legal solutions boasting long traditions. It cannot be denied that labour law is specific because its shape is the result of a compromise between labour and capital, which compromise must be regularly updated, given the degree of economic lability and market volatility. In a sense the victim of this situation is the existing Labour Code which, since its enactment, has undergone legion amendments, where the frequency and profundity of those amendments visibly increased as the political and economic transformation progressed. It is difficult to expect that it would be otherwise in the case of the new codification, the outcome of which will always be affected by the lobbies of trade unions or employer organisations ${ }^{21}$. On the other hand, however, it appears that a full decodification of Polish labour law is rather unlikely. Given that the Labour Code is strongly rooted in public awareness, it can be expected that any attempts to abandon this law would come up against a far reaching protest of the world of labour. This said, it needs to be concluded that in the years to come the process of amending the Labour Code is likely to be continued with concomitant erosion of its significance due to the shift of the gravity of legislation to other legal acts.

5. For many years a major challenge for Polish labour law has been unemployment. Notwithstanding certain fluctuations it still has the characteristics of mass unemployment. The links between labour law and unemployment are multifaceted. It would be difficult to question the fact that the legal relations that define the unemployed status are within the scope of labour law, although it can be reasonably claimed that they are not limited to it. Essential in this matter also are the regulations of administrative law (in the part pertaining to the organisational sphere and functioning of employment services) and social security regulations (in the part relating to benefits ${ }^{22}$. Given that the subject matter of labour law are employment contracts and other legal relations functionally linked to employment, it needs to be considered how this functional relationship presents itself in the case of

${ }_{21}$ M. Gersdorf, Podstawowe dylematy zwiazane z rozwojem prawa pracy w okresie transformacji ustrojowej [Primary Dilemmas of Labour Law's Development in the Transformation Period], „Praca i Zabezpieczenie Społeczne” 2003 [“Labour and Social Security” 2003], No. 5, p. 7.

22 More broadly discussed by Z. Góral, Bezrobocie a prawo pracy (wybrane zagadnienia) [Unemployment and the Right to Work], [in:] J. Stelina, A. Wypych-Żywicka (ed.), Człowiek, obywatel, pracownik. Studia z zakresu prawa. Księga jubileuszowa poświęcona Profesor Urszuli Jackowiak [Man, Citizen, Employee. Studies in law. Jubilee Book dedicated to Professor Urszula Jackowiak], Gdańsk 2007, p. 85 and following. 
unemployment. This is easy to notice when we assume a broad (social) approach to the employee status. In this broad approach an employee is any person whose social position is determined by gainful work for another entity. Consequently, being temporarily out of work does not exclude a person from the category of employees, as defined above. The right to assistance in finding a job is the subject matter of nothing else but labour law regulations, and the legal relations covering the exercise of this right are referred to as "legal relations in the preparation for entering into an employment contract", or more broadly "employment relations and unemployment prevention". In view of their specific nature, high diversity and dynamics ensuing from the variable situation on the labour market, they must be covered by a separate legal act. Certainly, this is not the subject matter of the future Labour Code, unless it happens to be enacted. The dynamic and complex nature of unemployment, its entanglement in the economic context cause Polish legislature to continually search, with moderate success, though, for optimum legal solutions in this respect. At that it is worthwhile to observe that since the start of the political and economic transformation the Parliament has passed four acts referring to unemployment, each of which has already been amended more than once. The existing act of 20 April, 2004 (on employment promotion and labour market institutions) ${ }^{23}$ has been frequently amended, too, and the latest extensive amendment was made on 12 May, 201424. It feels that in the course of enacting these regulations, which are extensive content-wise, grossly casuistic and unclear to the unemployed (they are rather addressed to the employment bodies), it is forgotten that for the purpose of fighting unemployment the law should only be ancillary to market mechanisms. Even though the set of unemployment fighting measures laid down in the laws and regulations is ever richer and more diverse, in general this does not translate into their effectiveness ${ }^{25}$.

Moderate hopes emerge from the afore-mentioned profound amendment to the existing act in reaction to the worrying situation on Polish labour market. After the favourable changes observed until the end of 2008, in 2009 those positive trends, i.e. the dynamic growth of employment and downfall of unemployment, slumped. At the end of 2009 the unemployment rate was $12.1 \%$, while at the end of 2008 it had reached the level of $9.5 \%$. In the following years the situation began to stabilise, with unemployment growth slowing down. In the years 2013-2014 the unemployment rate persisted at $13-14 \%$. In the reasons for amending the bill it was highlighted that the objective of the amendment was to enhance the effect of the labour market policy on employment growth and alleviate the effects of structural incompatibility, in particular in terms of qualifications and competencies of

${ }^{23}$ Consolidated text in OJ 2008, No. 69, item 415, as amended.

24 OJ 2014, item 598.

${ }_{25}$ More broadly discussed by E. Staszewska, Środki prawne przeciwdziałania bezrobociu [Legal Measures to Prevent Unemployment], Warszawa 2012. 
the unemployed. Brought to attention was the need to take the relevant measures for the unemployed to recover the skill of permanently joining in the job market, and to improve effectiveness of the labour market policy, job centres' operations, standards of the services provided to job centre customers, and employment ratio by introducing new forms of work organisation and collaboration between job centres and non-public entities. Additionally, it was found requisite to increase job centres' flexibility by better adjusting their services to the needs of the given unemployed and employer, primarily by providing real assistance to long-term unemployeds, taking measures to facilitate the balance between work and family life, and helping young people (up to 30 years of age) and older unemployeds (over 50) to enter and stay on the job market ${ }^{26}$. Doubtlessly, it must be admitted that the objectives set forth by the legislation are right. As regards the legal instruments applied to achieve the foregoing objectives, in terms of the legislative experiences to date, here and there they deserve to be called innovative. The changes focus on a few essential areas. One of the priorities strongly emphasised by the legislation is to improve the quality of the services provided to the unemployed accordingly to their needs. For this purpose job centres have adopted a new practice or serving the unemployed, based on the concept of support profiling, and concurrently introduced the customer counsellor function. Basically, the idea is to adjust support to the individual needs of the given unemployed - formulate appropriate job seeking programmes and select such forms which are most likely to help an unemployed enter or return to the job market. Prior to the amendment some labour market instruments were only addressed to, as distinguished by the legislation, "individuals being in a special situation on the labour market" (e.g. emergency works, public works, work experience schemes). Currently, job centres are to flexibly apply the labour market instruments and services to individual unemployeds taking into account the results of support profiling. In order to enhance the active labour market policy and support job centres in their actions to improve the services provided to the unemployed introduced has been a solution that enables the unemployed to access job seeking actions provided by external entities (outsourcing of job seeking tasks). Trilateral training agreements, which functioned in Poland until 2005, have been restored, which should translate into greater employment effectiveness of this labour market service. The second area of change is the introduction of new tools meant to help create jobs and facilitate the unemployed's return to work - especially those returning to the job market after a childcare break (grant for teleworking, job seeking allowances, loans to create a job or start a business). Another area of change are the numerous labour market instruments supporting employment of youth up to 30 years of age. A system of vouchers has been introduced (so-called training vouchers, work experience vouchers,

26 The rationale for the government bill amending the Act on Employment Promotion and Labour Market Institutions and certain other acts. Print No. 1949 available from www.sejm.gov.pl 
employment vouchers, settlement vouchers), as well as the option of refunding national insurance contributions paid for the unemployed up to 30 years of age who are taking their first job. The new instruments supporting employers employing unemployeds who are over 50 years of age have been structured likewise (e.g. co-funding compensations for employment of unemployeds who are over 50 years of age). In view of the necessity to achieve the targets of the Europe 2020 strategy, i.e. to build a competitive knowledge-based economy and prevent social exclusion of persons with low qualifications or competencies that are incompatible with the labour market needs, established has been the National Training Fund whose funds will be assigned to finance the measures taken to provide continuing education of employees and employers.

Finally, the last area of change is intended to improve job centres' effectiveness by making the funds transferred from the Labour Fund to cover the salaries and wages of county job centres' employees dependent on their effectiveness, as well as by increasing the role of social partners in the process of managing the Labour Fund's finances, programming and monitoring the labour market policy.

The foregoing changes are expected to improve the national indicators of employment and cost effectiveness of the primary job seeking forms in relation to the indicators achieved in the previous years. The changes, whose objective is to improve the quality of the services provided to the unemployed accordingly to their needs, should consequently cause the unemployed's average time out of work to be cut short, increase the percentage of job centre employees directly serving the unemployed, and increase the employment effectiveness indicator. The new labour market instruments addressed to the given categories of the unemployed should cut short the average time such unemployeds are out of work. Finally, what is desired is the growth of new jobs, including self-employed jobs created with the support of the Labour Fund.

6. Defining the relations between labour law and unemployment it feels right to pose the question what legal regulation of employment relationships may have an impact on the size and structure of unemployment. Not infrequent is the view that labour law is an unemployment generating factor for being excessively protective, hardly flexible, and for causing employment costs to increase. Consequently, despite the adopted amendments, Polish labour law is perceived to be unconducive to pro-employment attitudes of employers. Oriented at the protection of employees, i.e. persons who are already employed, it not necessarily stimulates creation of new jobs for the unemployed. This said, it is possible to claim that there exists a certain conflict of interests between employers, employees and unemployeds. One fundamental dilemma is whether labour law regulations are meant to protect the existing employment relations, or rather generate employment opportunities at the cost of job stability, as is the case with the flexicurity model. It is this model which, if adopted in Poland, can be seen as a way to solve 
at least some of the problems on the labour market in the nearest future. In this context it is also worthwhile to redefine the position of trade unions. Their organisational structure based on workplace organisations is sure to help represent the interests of the persons already employed by the company. To bring to trade unions' attention also the interests of the unemployed would require considering - as indicated herein above - the idea of setting up trade unions' operations outside the workplace. 